\title{
A FEW ASPECTS OF WELL-KNOWN ATHENIAN ISONOMIA IN ANCIENT GREECE AND ITS OPPOSITION TO THE PROFESSION OF A LOGOGRAPHER
}

\author{
KRYSTYNA TUSZYŃSKA
}

At the beginning of my article I should explain two terms used in the history of ancient Greek culture, that is LOGOGRAPHOS and ISONOMIA. Neither of them is definite. The first one, the Greek technical term LOGOGRAPHOS (English 'logographer'), was in the history of literature popularized by German philologist and archaeologist Georg Friedrich (1771-1858) and was considered to have been connected with two kinds of literary men: (1) the Ionian writer telling stories before Herodotus and (2) the paid speech writer in Athens in the fifth and fourth century B.C.

The first meaning is of little interest to us: the authors of the first ethnographical and geographical works did not distinguish facts from fiction; they are, nevertheless, the oldest prose writers in Greek literature. In the opinion of Thucydides, logographers composed their works with a purpose to impress the audience rather than to present the truth (Peloponnesian War, book I, 21.1).

The second term is linked with Athenian jurisdiction. The moral value of this term is my main interest in this article. The well-known Greek word ISONOMIA popularly meant no more than 'equality before the law'. The term is usually related to Greek democracy, but, interestingly, it was used not only in reference to Athenian democracy and not only by Athenian writers. First I am going to show the use of the two terms NOMOS and ISONOMIA in Greek culture, then to present a discussion of

\footnotetext{
${ }^{1}$ See: Gregory Vlastos, Isonomia politike, [in:] J. Man, E.G. Schimdt, ISONOMIA. Studien zur Gleichheitsvorstellung im griechischen Denken, Berlin 1964, p. 1.
} 
the question of the technical term NOMOS in Athenian literature and, finally, to describe the Athenian ISONOMIA as functioning through the people's court, the Heliaia, and to ask about the role played by the logographer in Athenian democracy.

Let me begin with the two elements which form the word ISONOMIA: isos and nomos. Isos in the most common translation means 'equal', but it also has the meaning of 'fair' or 'just'. In its second meaning, the adjective isos in ISONOMIA was used by Isocrates in his speech Panathenaicus (par. 178) in relation to Spartans and their moral norms ${ }^{2}$. We can also observe this kind of meaning of isos in the Athenian historian Thucydides; when describing the Theban spokesman, he relates to Thebes' political system as 'a government which is neither kat' oligarchian isonomon nor a democracy' (Peloponnesian War book III, 62). In this sense the adjective isonomos is connected with oligarchy. But, as G. Vlastos wants it, the aim of Thucydides was to put an emphasis on a totally different type of government 'a dynasteia (English 'government') of a few men' which is ruled arbitrarily in the way closest to tyranny, without giving the people any voice in its decisions, which is attributed to the Theban government. However, Thucydides did not mean to distinguish between Athenian democracy and oligarchy ${ }^{3}$.

We can also find the term ISONOMIA in non-Athenian texts. The earliest piece of evidence that has come down to us is the constitutional document from Chios which reveals the existence of a number of democratic institutions on that island as early as about $575-550 \mathrm{BC}$, for example meetings of a popular assembly in some judicial capacity. Other examples of such texts are those associated with an egalitarian system of government in the island of Samos, after the death of tyrant Polycrates (522 B.C) and the democratic reforms of Demonax of Mantinea enacted at Cyrene about the middle of the sixth century BC. ${ }^{4}$

The survival of substantially more literature and inscriptions from Athens than from any other part of the Greek world often makes us oblivious of our ignorance of the history of the rest of Greece. However, the silence of our sources from other city-states does not seem to be a sufficient argument for the term's origin in Athens ${ }^{5}$. In short, we lack the information which would enable us to affirm or deny with any confidence that the ideas of ISONOMIA or NOMOS as 'statute' originated in Athens with Cleisthenes' reforms (about 508 BC.), but, of course, in popular thinking ISONOMIA and DEMOKRATIA are synonymous.

What is also interesting for me is the Greek term NOMOS. NOMOS is a 'law' or a 'norm' in a descriptive sense, and although the origin of this norm may be on vari-

${ }^{2}$ This example is extensively discussed (especially regarding its use by the Athenian writer) by G. Vlastos, op. cit., p. 18-21.

${ }^{3}$ G. Vlastos, op. cit., p. 13-17.

${ }^{4}$ See: Martin Ostwald, Nomos and the Beginnings of Athenian Democracy, Oxford 1969, p. 96-136 (discussed at length).

${ }^{5}$ It is an opinion of M. Ostwald, op. cit., p. 97. 
ous occasions attributed to the gods, to a lawgiver, or to an enactment by the society as a whole, the main point is that, regardless of its origin, it is recognized and acknowledged as a valid norm within a given milieu ${ }^{6}$.

But as it is worth mentioning at this point, we do not have a precise understanding of the technical term of NOMOS. Eric Dodds in his book titled The Greeks and the irrational $^{7}$ underlines the fact that NOMOS had for the Greeks as many as three distinct meanings: law, custom and social conventions. Of course, to make our considerations more clear we can agree that what is interesting for me now is the first meaning of the term, i.e. law. But in the fifth century BC, thanks to sophists, there arose in Athens a nomos-physis antithesis. What is physis then? The term is usually translated as 'nature'. It was a term which Ionian 'scientists' came to use for the whole of reality, or for the most abiding material source. But it also came to be used to refer to the constitution or set of characteristics of a particular thing, or class of such things, especially of a living creature or a person ${ }^{8}$.

There are some deep differences in the use of this term by sophists and philosophers: physis (English 'nature') can be common unwritten law which is in accordance with nature (in this meaning it is used by Aristotle in his Rhetoric $1370 \mathrm{~b}$, and also in Greek drama, in Antigone by Sophocles, when Antigone appeals to unwritten, divine NOMIMA contrasted with laws determined by men. And also, in another meaning, physis is a source of values and its appeal was simply to the nature of things, essentially to the nature of the phenomenal world. That is what can be seen in the words of the sophist Hippias in Plato's dialogue Protagoras (337 c-e) when he addresses those (sophists and their pupils, and also Socrates) present in the house of Callias with the words: I for my part regard you as all kinsmen and belonging together and as fellow-citizens, by nature and not by law; for like is akin to like by nature, whereas law, a tyrant over human beings, in many things constrains us contrary to nature (physis). So we are dealing with the nomos-physis controversy here.

But in another dialogue by Plato, Gorgias, we can find a different meaning of this antithesis. Statesman Callicles proves that for the most part nature and NOMOS are opposed to each other. But in another way: conventional laws are made by the majority who are weak. They make them in their own interest, and, being inferior, they are happy to settle for equal shares. Consequently, by virtue of NOMOS it is thought unjust and shameful to seek to have more than is possessed by the majority. But by nature, it is right that the better should have more than the worse and the abler more than the less able. The same meaning of the term NOMOS we can observe in The Peloponnesian War by Thucydides in the famous rhetorical piece known as The Melian Dialogue (book V, 84-116). Thucydides himself was a child

\footnotetext{
${ }^{6}$ This is a popular definition of NOMOS. Cf. M. Ostwald, op. cit., p. 20/21.

${ }^{7}$ Eric Dodds, The Greeks and the Irrational, Berkeley 1951. I have read it in the Polish translation by J. Partyka, Homini, Bydgoszcz 2002 (p. 147).

${ }^{8}$ G.B. Kerferd, The Sophistic Movement, Cambridge 1981, p. 111.
} 
of the sophistic movement in both its philosophical and rhetorical branches and, because of the nearly total lack of extant sophistic works that we could resort to, he has been our representative source of the theories of the sophists ${ }^{9}$. The Melian Dialogue, conducted between the Athenians and the Melians, derives its structure from Protagorean treatises Antilogiai (Contradictory Arguments), of which one extant example is the late fifth-century pamphlet titled Double Arguments (Dissoi logoi) ${ }^{10}$. Protagoras illustrated in this treatise his contention that there are two opposite arguments on every subject. In the Melian debate there is portrayed the extreme imperialism of the Athenians directed against the helpless enemy and the term NOMOS means here no more than 'the law of the stronger' which can be understood as 'nature's law'. Thucydides was very interested in the power of logos; he was a representative of a new intellectual school, much influenced by rhetoric and sophistic ideas ${ }^{11}$. It is now clear that the term NOMOS was discussed by Greek philosophers, historians and literary men, especially in Athens, however a conclusive analysis of it is far from obvious for both philologists and historians.

At this point, we have to refer shortly to another term which is important here, namely THESMOS, an older term in Athenian tradition than NOMOS. The fundamentals of democracy were laid by Solon's reforms (594 BC). But Solon himself did not use the term NOMOI to describe his reforms. Rather, he used an older term, THESMOI. I am not going to discuss the definition of THESMOS in detail here. Suffice it to say that the word has a few meanings, the most important one for us being 'specific statutes or regulations of a political or religious character' ${ }^{12}$. One observation would be of some importance here: if we apply the significance of THESMOS as 'a thing imposed by a higher power upon those for whom the authority of the imposing agency makes the THESMOS an obligation' to the sense of 'statute', we may conclude that THESMOS is a law given by a lawgiver who is thought of as standing apart from and above the persons upon whom his law is binding ${ }^{13}$. As I have already stated, Solon himself did not use the term NOMOS to describe his legislation, but Aristotle, speaking on his own behalf when discussing Solon's reforms, uses the very term NOMOI (Constitution of Athens 7-12) ${ }^{14}$. During the fifth

\footnotetext{
${ }^{9}$ W.C.K. Guthrie, A History of Greek Philosophy, Cambridge 1969, p. 223-224.

${ }^{10}$ Henry Immerwahr in the chapter on Greek historiography (p. 446) in The Cambridge History of Classical Literature, Part one: Greek Literature, ed. by P. Easterling and B. Knox, Cambridge 1985.

${ }^{11}$ Thucydides himself presents his methodology as a historian at the beginning of his History of the Peloponnesian War: 'My habit has been to make the speakers say what was in my opinion demanded of them by various occasions, of course, adhering as closely as possible to the general sense of what they really said'. (book I, 22.1), in translation by Crawley, London 1910.

${ }^{12}$ For a very interesting discussion of the term THESMOS see: M. Ostwald, op. cit., p. 1-19.

${ }^{13}$ See: M. Ostwald, op. cit., p. 19.

${ }^{14}$ Aristotle's Constitution of Athens is the sole surviving example of a massive investigation of Greek city states which Aristotle directed, though he himself could hardly have written more than a fraction of the 158 treatises which were reputedly composed.
} 
century the technical term for 'statute' in Athens changed from THESMOS to $\mathrm{NO}$ $M O S$ and since those times the two terms have carried different meanings. Solon's legislation laid foundations for democracy, but did not enforce a democratic system in Athens. Aristotle described Solon's reforms as mese politeia, the form of government transitional between oligarchy and democracy ${ }^{15}$. Solon did for the poor as much as he could in the political and social system of Athens. He did not make the poor and the rich equal but he did make them equal before the law.

The next step in Athenian democracy is due to the reforms of Cleisthenes. It could be said that thanks to them the two terms of DEMOKRATIA and ISONOMIA are very close to each other. ISONOMIA is the principle of political equality. It is not a constitutional form; it ensures, for all citizens, an equal chance to be elected for office, equality in holding magistrates accountable for their official acts, and an equal opportunity to participate in the shaping of policies ${ }^{16}$. Aristotle says (Constitution of Athens 20,1) that Cleisthenes opened the political life in the city to the people as a whole. As I said at the beginning of my article, neither of the terms - NOMOS or ISONOMIA - is, beyond dispute, of Athenian origin. So the question is: can we speak of the source when referring to Cleisthenes? My answer is: yes, because the adoption of NOMOS in Athens was the result of a deliberative policy (as I have shown in the discussion about the very different meanings of the term NOMOS in Athenian literature) and the implementation of that policy. And even if Cleisthenes did borrow both NOMOS and ISONOMIA from other parts of the Greek world, he was original in that he was the first to combine them in a way in which no other state is likely to have combined them before. And, what is more, through ISONOMIA he expressed the principle and the instrument of Athenian democracy.

After these remarks, we should ask: who did NOMOS serve in Athens in the fifth and fourth century BC and how should we understand the term ISONOMIA in Greek democracy? When democracy is identified with ISONOMIA, we understand 'democracy' in the most positive way as something akin to 'the management of public affairs is made common' and 'the power is given to the masses' ${ }^{17}$.

The most important institution of the democratization of life in Athens was the Heliaia, meaning 'the people's court ${ }^{18}$.

${ }^{15}$ See: Stanisław Witkowski, Państwo greckie, Warszawa 1938, p. 217.

${ }^{16} \mathrm{M}$. Ostwald says that the Greek ISONOMIA comes closer than any other Greek word to expressing the modern notion of 'rights' in the sense in which we speak of the 'rights of man' or 'rights of citizen'. Cf. M. Ostwald, op. cit., p. 113.

${ }^{17}$ These are the definitions given by Herodotus in a political debate in his History (book 3, 80.2; 81.1).

${ }^{18}$ In the Heliaia the 6,000 citizens were drawn from the 10 tribes and they were divided into chambers of 600 jurymen, 500 or 501 of whom were regular members, with the rest constituting alternate jurors. It should be noticed that the Heliaia's jurisdiction also included Athenians and citizens of other cities as a subjects of international law. 
Now, we can go further to Pericles' reforms implemented with the aim of full democratization of Athenian life. As has been said before, the Heliaia, the people's court, was one of the most important instruments of ISONOMIA ${ }^{19}$. Initially, the Heliaia's jurisdiction was limited to judging the archons and, probably, dealing with some other similar accusations against public office-holders. It was when Ephialtes and Pericles prompted a binding resolution through the ecclesia, striping the conservative Areopagus ${ }^{20}$, of most of the cases it decided, that the Heliaia started hearing almost all the civil and penal cases ${ }^{21}$. Taking the jurisdiction over the so called graphe paranomon ${ }^{22}$, the Heliaia replaced the Areopagus in the execution of legal control of the decisions of the ecclesia. Of much importance is the fact that there was no appeal to any other tribunal, because the people's court was the highest one in Athenian democracy.

The Heliaia was a court the member of which could be every citizen who was over thirty years old, without exception. There was not any so-called dokimasia, i.e. examination of candidates chosen to the people's court from the point of view of their morality, abilities, knowledge of the law and other factors of this kind. The public office of the heliast was not obligatory, and the citizens who wished to exert these duties had to submit a petition. Pericles' idea was to make it a custom of paying the so-called misthos, meaning 'judicial allowance', to every single judge in the people's court, the payment being made per one day spent in the court. According to Aristotle, Pericles first made in the jury-courts a paid office, as a popular counter-measure against Cimon's wealth ${ }^{23}$. The salary of each day of employment was one obolus, and later, three oboloi, i.e. half of a drachma, assuming the heliasts were ordinary citizens and not legal experts.

This kind of transformations in public life had their reflection in Greek performances in the theatre, particularly in the so-called Old Comedy. We also have to note here that Athenian theatre can be perceived as the world in miniature. The performances presented on the stage at the foot of the Acropolis constituted a part of religious celebrations worshipping Dionysus, and all the citizens were legally

${ }^{19}$ About the Heliaia as an instrument of ISONOMIA see S. Witkowski, op. cit., p. 213 and the following.

${ }^{20}$ The Greek name Areios Pagos translated 'Ares' Rock' functioned as a court for trying deliberative homicide. Before Ephialtes' reforms the Areopagus had had the duty of guarding the laws and to keep watch over the greatest and the most important affairs of the state. Source: Aristotle, Constitution of Athens 8, 1.

${ }^{21}$ The Areopagus kept its competence only for the crimes of murder and arson while the archons could impose some minor fines. See: S. Witkowski, op. cit., p. 213.

${ }^{22}$ Graphe paranomon was a form of legal action believed to have been introduced in Athens under the democracy somewhere around $415 \mathrm{BC}$. It was a replacement for ostracism which had fallen into disuse around the same time. The term means 'suit against (bills) contrary to the law'. For an explanation of the term see: S. Witkowski, op. cit., p. 229-230.

${ }^{23}$ Aristotle, Constitution of Athens 9. 
obliged to participate in them ${ }^{24}$. In this way, as Ewa Skwara ${ }^{25}$ very rightly underlines, the Athenian performances created an ideal space in which the theatre fully reflected society and could simultaneously mould it. It may now be very difficult to understand the function of the theatre in the Athenian community, because the theatre has lost this ability - to be the world in miniature - as compared to such media as television and the Internet. But in ancient Athens in the fifth century BC, all citizens participated in theatrical festivals, and Aristophanes, the most representative poet of Old Comedy, himself said in the Frogs that the theatre had the same importance for adults as school for children: the duty of the theatre is to educate the society of the $\operatorname{state}^{26}$.

What we know about so called Old Comedy still depends, in overwhelmingly large measure, on the selection of eleven plays by Aristophanes which have survived in medieval copies. For all their variety of theme and incident, Aristophanes' plays have a common basic pattern: a revolutionary idea, a way to change a situation which hero will not tolerate, is carried against opposition and pursued through some of its consequences which are good for some and bad for others. Aristophanes' heroes represent real people of present or, sometimes, past (except two familiar figures from myth, Heracles and Dionysus). And it is a good question how true to life the 'real people' are or were ever supposed to be.

The art of Aristophanic portraiture is well compared to that of modern newspaper cartoonists, it exploits, and indeed helps to create, the popular image of public figures, and it will sometimes present a satirical hybrid between the real person and a second imaginary identity. And the most important thing, Aristophanes' characteristic feature is the decline in political, social and personal satire which he has given in his plays.

Incidentally, one of the late comedies of Aristophanes, the Wasps, shows the poet's interest in the judicial system in Athens. The Wasps was staged at the Lenaia festival in $422 \mathrm{BC}$. There are presented two main heroes in it, Philocleon whose name can be translated into English as 'lover of Cleon' ${ }^{27}$ and Bdelycleon, whose name should be understood as 'hater of Cleon'. Philocleon is portrayed as a wild and cantankerous old man, addicted to litigation and the excessive use of the people's

\footnotetext{
${ }^{24}$ Equal access to the theatre for all citizens, both rich and poor, was guaranteed by so the called theorikon - a theatrical fund whose character remains partly unknown. It amounted to two oboloi, which equaled one day's pay of an unqualified worker. It is assumed that one obolus comprised the price of the ticket and the other costs were connected with the participation in the festivals. See: R. Chodkowski, Teatr grecki, Lublin 2003, p. 237.

${ }^{25}$ Ewa Skwara Laughter at Seriousness - Authority in Comedy, [in:] Authority in the Past and Present, ed. by Kazimierz Ilski and Krzysztof Marchlewicz, Poznań 2013, p. 122.

${ }^{26}$ This kind of teaching on the part of that dramatist is clearly presented in the 'Stasimon' of the Frogs (1105-1118).

${ }^{27}$ Cleon was a public speaker and demagogue, hated by Aristophanes.
} 
court system. Bdelykleon, on the contrary, is portrayed as a reasonable, law-abiding and civilized young man. Old Philocleon, has at last been turned, by a trick, away from his passion for jury-service which has obsessed him so far: on a typical day he would wake up at day-break, go quickly to the people's court (only the first citizens to show up, and whose number was limited, were paid the misthos), and spend in the court all day. All this gave him the satisfaction of being a man useful to the city and interested in its public life. There is clearly an overt political suggestion in the play that Athens needed to sweep away the old corrupt regime, and replace it with a new young order of defence and honesty.

In fact, a great number of Athenian citizens were like Philocleon: old men, without education needed for jury-service, hungry for judicial allowance which could provide money needed to support the family (misthos was a day's pay of an unqualified worker ${ }^{28}$ ). For this reason, participation in the people's court was not what the rich citizens were interested in. That is why, according to Aristophanes, the members of the Heliaia were almost exclusively old, uneducated, poor people. Interestingly, in a short time the people's court had become the strongest judicial, lawgiving and administrative power.

Aristophanes' another comedy, performed in $414 \mathrm{BC}$ at the City Dionysia festival, the Birds, shows his interest in the Athenian system of jurisdiction: the Birds begins with an entry of two men who are on a journey to the world above the earth, a world free from trials in the people's court which plagued Athens. The dramatist presents an escape from our world physical transposition of the action into another one $^{29}$. The idea of this comedy is that two people leave Athens in search of peace and quiet and end up founding a new city in the sky, Nephelokokkygia - the 'Cloud Cuckoo Land' whose name has entered the English language as that of a kind of Utopia. Gilbert Murray ${ }^{30}$, for whom the Birds is a type-example of a 'play of escape', gives a good sketch of the trials and tensions of Athenian home and foreign affairs at the time of the play, from which an escape would no doubt have been welcome. Aristophanes in this comedy compares the heliasts who always run in a hurry to the people's court to clouds of birds which are looking for prey. We have no doubts that, compared with hungry birds, the heliasts stand for poor citizens. For them, as in the previously-mentioned comedy by Aristophanes, misthos (here presented as 'prey') is the only opportunity to support the family with. In the Birds

\footnotetext{
${ }^{28}$ See: S. Witkowski, op. cit., p. 231.

${ }^{29}$ Popular fiction is used by writers in general and the fifth century Greek comedy is no exception in this respect. The very idea that people are travelling, be it far or near, is one that can be relied upon to make the reader or the audience take notice. Three other plays out of the eleven surviving by Aristophanes begin with two people going somewhere. For more information see: the chapter: Adventure and Fantasy, [in:] The Cambridge History of Classical Literature, I, Greek Literature, ed. by P. Easterling and B. Knox, Cambridge 1985, the chapter Comedy by E.W. Handley, p. 355-425.

${ }^{30}$ Gilbert Murray, Aristophanes: a study, Oxford 1933.
} 
there is underlined another feature of the Athenian jurisdiction system, i.e. the profession of a sycophant ${ }^{31}$. I will treat this profession at large in the next paragraph, but I am going to observe at this moment that Aristophanes presents this profession as a very dangerous feature of the whole Athenian jurisdiction. Because of the profession of a sycophant, as says Aristophanes, no one can be safe, even children in the bosom of their mothers. Also in this comedy, the main heroes bear significant names, i.e. the first one, Peisthetareus, means 'trustworthy friend', the other one, Euelpides, means 'good hope'.

Both comedies, the Wasps and the Birds, are evidence of Aristophanes' deep interest in the shortcomings of the Athenian institution of the Heliaia and the whole system of Athenian jurisdiction.

One fact should be noticed here: the profession of a lawyer is not known in Athenian jurisdiction $^{32}$. Every litigant had to defend himself or accuse another citizen on his own. All arguments in the trial were presented by the litigants themselves, without legal support of a lawyer, in the form of an exchange of single speeches timed by a water clock. In a public suit each litigant had three hours to speak, whereas they had much less time at their command in citizen suits. In this way the judicial cases became a vehement fight to make an impression upon jurors, since they did not constitute a relatively small group of mature citizens, such as the Court of Areopagus which was interested only in the correct application of the law. Additionally, each citizen had to become an effective orator before the chambers of the Heliaia and to act in his capacity as a citizen in order to protect his interests and enforce his views ${ }^{33}$. Decisions were made by voting without any time set aside for deliberation. The voting procedure was public and transparent. Each heliast had received two votes, one 'guilty', and one 'not guilty'. The herald would first ask the heliasts if they wanted to submit any objections against the witness and, then, he would call on them to cast their votes in two different amphora. On the other hand the voting was secret, since each juror would cover the vote with the fingers, so that nobody could see in which amphora he threw a particular vote ${ }^{34}$. To be most persuasive before the people's court was the only hope of each litigant.

In this situation, the profession of a logographer, or a speech writer, known as a consultant, became a very important one. And it is the litigant who had to pay for the consultant's services. A logographer, a kind of a consultant, depending on his client's wish, could compose a complete forensic speech for the litigant or could compose only its introduction and the argumentative section, or, alternatively, he

\footnotetext{
${ }^{31}$ The Birds 1415 and following.

${ }^{32}$ First 'lawyers' were the Romans.

${ }^{33}$ See; Stephen Usher, The orators in Ancient Attica in the Modern Educational System, Editions Grigoris 1984, p. 184.

${ }^{34}$ See: R.K. Sinclair, Democracy and Participation in Athens, Cambridge University Press 1991,
} p. 20. 
could instruct the litigant on the presentation of the case. He could give him advice on the sequence of arguments and on the emphasis of individual points of the rhetorical composition. Rich litigants could spend more money on the services of a logographer who was held in high repute and had experience in court cases.

One of the famous logographers, well known in the field of forensic oratory, was Lysias, portrayed by Plato in his dialogue Fedrus. But the profession of a logographer was linked in popular mentality with another profession, a synegoros, socalled 'co-speaker', an advocate, who helped the litigant, sometimes as a friend, but sometimes expecting some kind of gratification, for example, giving him a push in political life.

The profession of a logographer, in the long course of Athenian democracy, became more and more dishonourable ${ }^{35}$. The famous orators, like Isocrates, often denied that in their youth they had entered the profession of a logographer, or - like Demosthenes ${ }^{36}$ and Aeschines accused one another of acts of dishonesty committed when they had been logographers. The most popular objection against dishonest consultants was their venality: there were not infrequent cases of consultants who, for better payment offered by the other side of the lawsuit, sold their well-prepared speeches to their original client's opponent ${ }^{37}$. Of course, the result was the former client's defeat in the trial. Another famous Athenian orator, Antiphon, gave advice on the composition of the forensic speech to Athenian citizens not for payment, but for personal political advantage ${ }^{38}$.

There is also a third kind of profession linked with the two mentioned above, i.e. the logographer and the synegoros, which in fact was held in utmost contempt by most of Athenian citizens. It should be observed that verdicts given by the Heliaia were often prejudiced against the accused and the prejudice was infrequently based on 'reports' made by 'an army' of people who were ready to witness against other citizens in the people's court. Those infamous people were called sycophants ${ }^{39}$.

The traditional view is that the opprobrium directed against sycophants was attached to their bringing up an unjustified complaint, hopping either to obtain the payment for a successful case or to blackmail the defendant into paying a bribe to

\footnotetext{
${ }^{35}$ See: R. Turasiewicz, Życie i twórczość Lizjasza. Początki praktyki retorycznej, Kraków 1999, p. $38-41$.

${ }^{36}$ Demosthenes earned a lot of money by preparing speeches for Phormion, Cthesiphon and his other clients and in a short time he became one of the richest men in Athens. Yet we tend to remember him only as the best of the Ancient orators. Confer: R. Turasiewicz, op. cit., p. 37.

${ }^{37}$ See: R. Turasiewicz, op. cit., p. 37.

${ }^{38}$ See: G. Kennedy in the chapter Oratory [in: The Cambridge History of Classical Literature, op. cit.], p. 501.

${ }^{39}$ A short definition of a sycophant is as follows: the sycophant disparaged the unjustified accuser and who had in some way perverted the legal system. But the term which was in use in classical Athens was 'a servile self-seeking flatterer'.
} 
drop the case $\mathrm{s}^{40}$. The famous Athenian writers such as Xenophon, Plato, or Aristophanes pronounced against this shameful profession ${ }^{41}$. Sycophants included those who profited from using their social/political position. For instance, one could hire a sycophant to bring a charge against his enemies or to take a wide variety of actions of an official nature with authorities, including introducing decrees, acting as an advocate or a witness, bribing ecclesiastical or civil authorities and juries, or dealing with some other questionable matter with which one did not want to be personally associated. Thus, sycophants were viewed as uncontrollable and parasitic, lacking proper regard for the truth or justice in any given matter, using their skill and education to destroy their opponents, for profit matters where they had no stake in the trial, and having no sense of serving the public good ${ }^{42}$.

I can also add to in my considerations the fact that the two well-known logographers, Lysias and Lycurgos, had to defend themselves against charges that they were sycophants because they had prosecuted cases as private citizens in circumstances where they had no personal stake in the underlying dispute. Lysias defended himself in the forensic speech Against the grain dealers (or. XXII, par. 3, in Corpus Lysiacum), and Lycurgos in his only surviving forensic speech Against Leocrates. The charge of sycophancy against a litigant was a serious matter. But in each instance, the lack of personal involvement appears to have been the crux of the sycophancy accusation against them, the merits of the cases being a separate matter from whether they had the right to bring them or not ${ }^{43}$.

A meaningful insight into the nature of the profession of a sycophant could be gained by a careful analysis of the following three comedies by Aristophanes: The Acharnians, the Birds and Wealth. The three plays have numerous references to various sycophants and, predictably, portray them in a very unfavourable light.

The aim of my article has been to draw our attention to the fact that we should be conscious of the very ambivalent meaning of such ancient Athenian terms as NOMOS, ISONOMIA and logographer. We are not sure of the provenience of the terms NOMOS and ISONOMIA as used in Athenian social and political life. We should, therefore, revise our judgment in the matter of so fundamental an instrument of democracy as ISONOMIA, and we should be more careful in our opinions about the profession of a logographer.

\footnotetext{
${ }^{40}$ M. Mac Dowell, Law in Classical Athens, Ithaca NY Cornell University Press, 1986, p. 62-66.

${ }^{41}$ See: R. Turasiewicz, Życie polityczne $w$ Atenach V i IV w. przed n.e. $w$ ocenie krytycznej wspótczesnych autorów ateńskich, Ossolineum Wrocław 1968, p. 144-160. It should be noted however that other scholars have suggested that the sycophant, rather than being generally disparaged for being motivated by profit, was instead viewed as a vexatious litigant who was over-eager to prosecute, and who had no personal stake in the underlying dispute, but often brought up old charges unrelated to himself long after the event. For this point of view see: S. Allen Danielle, The World of Prometheus. The Politics of Punishing in Democratic Athens, Princeton University Press 2003, p. 156-164.

${ }^{42}$ Josiah Ober, Mass and Elite in Democratic Athens, Princeton University Press 2009, p. 173-174.

${ }^{43}$ See: S. Allen Danielle, op. cit.
} 
Our admiration for the great achievements of Greek oratory does not always go hand in hand with our appreciation of the morality of single orators. Of course, if we ask about the morality of the people's court we can also ask about the morality of logographers. In this way, we can come to a conclusion that any satisfactory answer does not exist. In the light of the ancient sources, we can say that we possess more evidence of honest verdicts in the people's court and of valuable speeches given there than of acts of dishonesty. And the Attic comedy was always a little distorted mirror of reality, particularly through the person of Aristophanes.

I should like to present my last remark at this point: Athenian philosophers such as Plato and Aristotle had their own vision of a political system, and each of them a different one. For Aristotle, the best political system was politeia, meaning a middle system between democracy and oligarchy, in which magistrates would belong to the best of citizens, the most qualified in their natural abilities. Plato, on the other hand, disappointed with Athenian democracy for a few reasons (one of them was the death of his lovely master and teacher Socrates in 399 BC as a consequence of a verdict of the democratic Heliaia), wrote The Republic, the first Utopia in European literature and philosophy. The question of the best instrument of political life in the state is, in my opinion, still open at present. 